\title{
GLL
}

Geomatics, Landmanagement and Landscape No. $3 \cdot 2019,7-16$

\section{ANALYSIS OF GENERALLY AVAILABLE ONLINE SOURCES OF SPATIAL DATA IN THE CONTEXT OF APPRAISING HISTORIC REAL ESTATE PROPERTY}

\author{
Agnieszka Bitner, Karol Król, Piotr Piotrowski, Sabina Gajczak
}

\begin{abstract}
Summary
The paper presents an analysis of generally available (open access) online sources of information - such as geoportals - in order to assess how valuable they are to the work of a real estate property appraiser. As a result of the analysis, it was determined what information is available in geoportals about a specific real estate property, which would be relevant in the valuation process. The property in question is located in the Dolnośląskie (Lower Silesian) region, Średzki district, Środa Śląska municipality. It is a property of a historic-cultural value.

Two nation-wide geoportals were examined, as well as regional and local geoportals from the Lower Silesia region, where the valued object is located. Three categories of geoportal assessment were applied in this study, namely: functionality, transparency, and the availability of information about the valued property; the latter being the most important from the property appraiser's point of view. The analysis showed that geoportals provide information relevant to the real estate property in the valuation process. The levels of information availability in the studied map portals were shown to have varied. Of course, this kind of information requires verification, because not all portals provide the date and time of the last information update. That notwithstanding, they still constitute valuable sources of information about the real estate property.
\end{abstract}

\section{Keywords}

historic property $\bullet$ geoportal

\section{Introduction}

When determining the method, approach and technique of valuation, a property appraiser uses many sources of information about the valued property [Bitner and Bysina 2014]. These sources include, for example: land and mortgage register, real estate cadastre, land and building records, and local spatial development plan. The development of information technologies [Król and Szomorowa 2015] and the availability of the Internet have significantly enriched the toolkit of property appraisers with additional sources of information about real estate. These include, but are not limited to, websites that contain spatial information - that is, geoportals. They constitute a national geoinformation system 
built on three levels: nation-wide - which covers the entire territory of Poland; regional - which applies to the area of the given region; and local - which covers the area of the given municipality or district [Salata et al. 2015, Dawidowicz and Sońta 2014, Siejka and Ślusarski 2014]. The main legal provisions regulating the principles of constructing and developing the domestic spatial information infrastructure are the INSPIRE Directive [Directive 2007] and the Act on Spatial Information Infrastructure [Act 2010]. According to the INSPIRE directive, "the main purpose of building and maintaining an infrastructure for spatial information is to collect spatial information data, to facilitate combining spatial data sets provided by various entities, to share network services related to these data sets, and to facilitate their shared and joint use by administrative bodies and other users, as well as the facilitate their use across many various systems, applications, sources of origin and formats" [Salata et al. 2015]. In turn, the Act on Spatial Information Infrastructure of 4 March 2010 [Act 2010] regulates issues related to the construction and development of the national geoinformation system. The purpose of the present work was to analyse the available sources of information that the geoportals are, in order to assess their usefulness in the work of a property appraiser who prepares an appraisal report for a specific type of real estate property, which is a historic (heritage) property.

\section{Location and description of the historic real estate property}

The property in question is located in the Dolnośląskie (Lower Silesian) region (województwo), Średzki district (powiat), Środa Śląska municipality (gmina), in the town of Szczepanów. The location of the town against the background of the district is shown in Figure 1.

The property subjected to valuation, located in Szczepanów, is a plot of land built up with a historic palace surrounded by a park. The palace and a part of the park are located on plot No. 970/16. Photographic documentation of the property is presented in Figures 2, 3, and 4. The property is gravely neglected.

Historic monuments are one of the most important elements of cultural heritage as material achievements of past generations. These are special properties with unique features that distinguish them from other types of real estate [Bogdani et al. 2015]. The features that distinguish them from other real estate properties are their historic and architectural values. These properties require special legal protection, which is associated with restrictions on their use, disposal, management and modernization. Legal protection of monuments is provided by the Act on the Protection and Preservation of Historic Monuments of July 23, 2003 [Act 2003].

In the process of historic properties' valuation, it is required that more information be obtained about these properties with respect to their unique features and potential uses [Kienast et al. 2012, Felcenloben 2011, Gołembski 2005, Nassauer 2012]. The stock of historic real estate, in relation to the entire real estate stock in Poland, is very limited. The market of historic real estate is a domestic market. Since typically, at most, there is only one such property available in the local market at a given time, the transactions in that market take place only sporadically. 


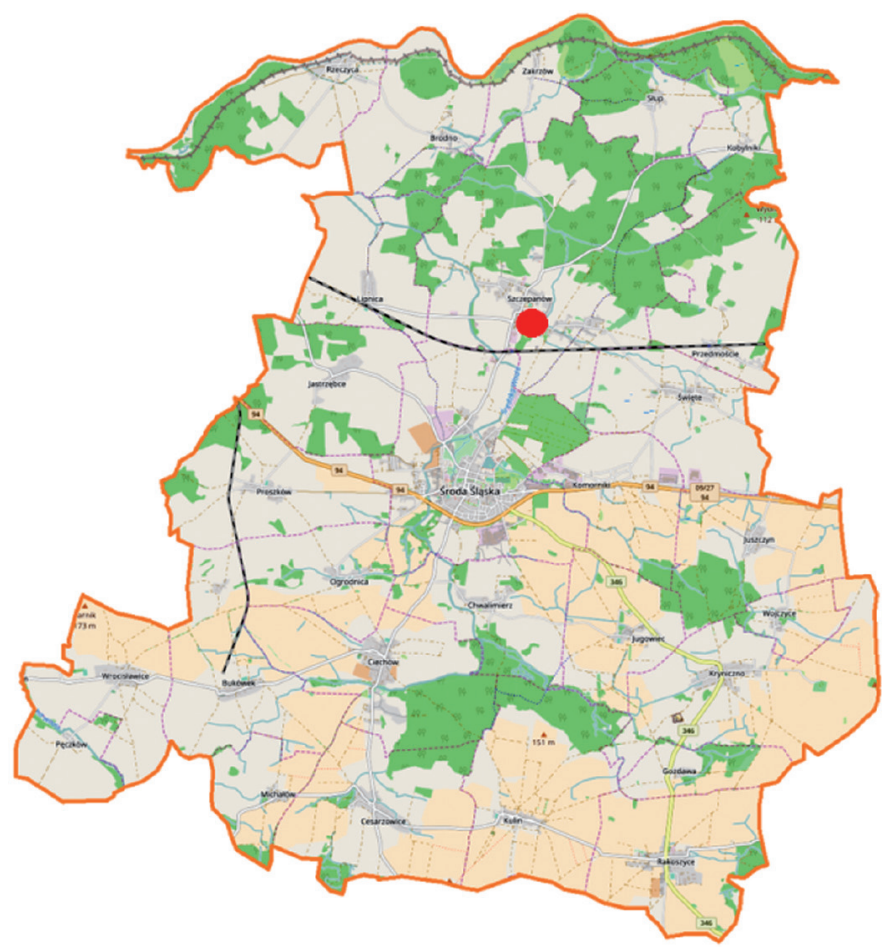

Source: http://gis1.madkom.pl/psip

Fig. 1. Location of Szczepanów town against the background of the district

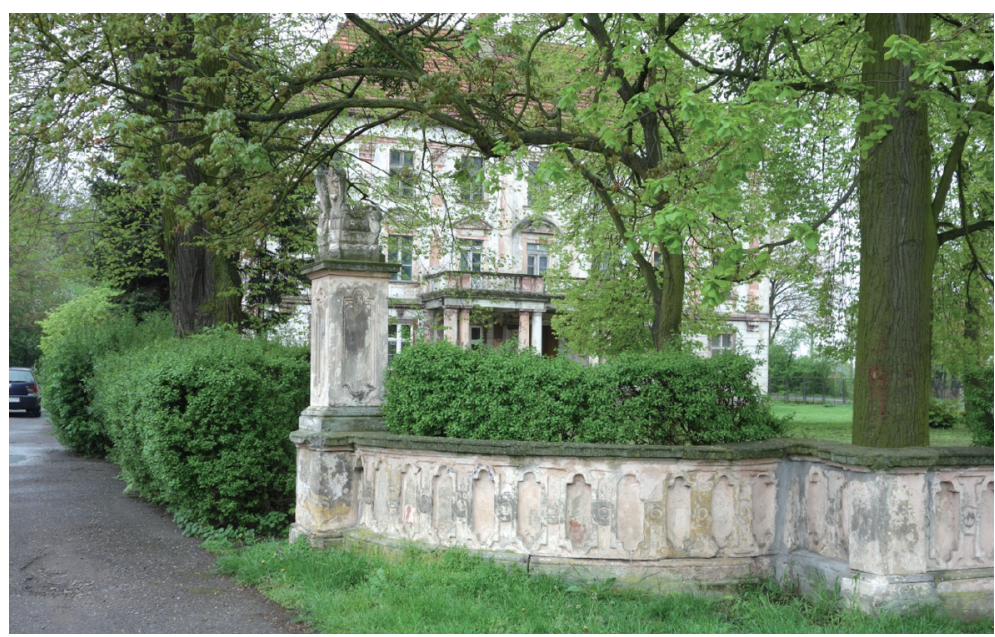

Photo by Sabina Gajczak

Fig. 2. Front view of the palace, with a historic fence

Geomatics, Landmanagement and Landscape No. 3 • 2019 


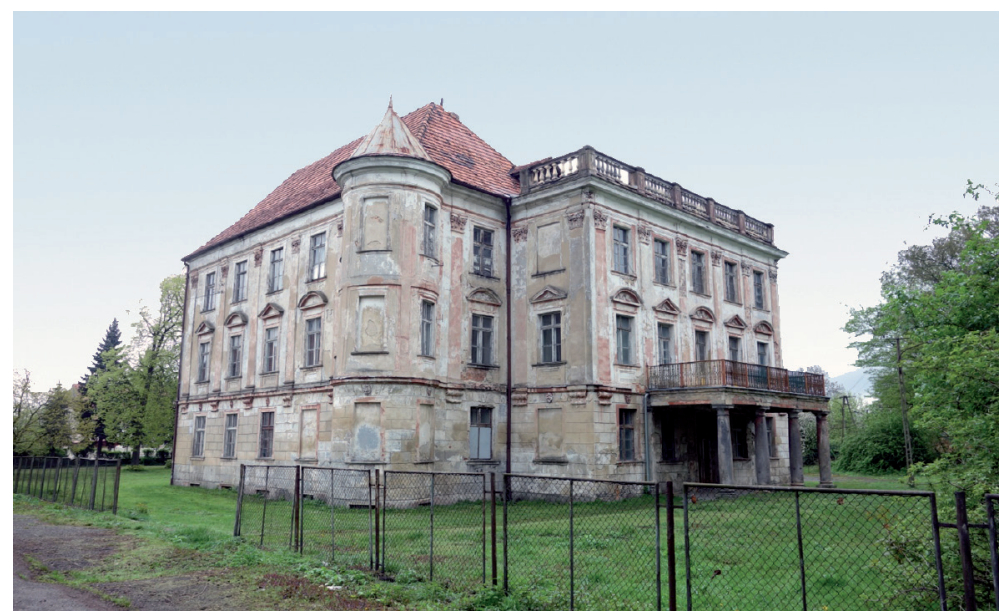

Photo by Sabina Gajczak

Fig. 3. Garden view of the palace - from the site of the former ornamental garden

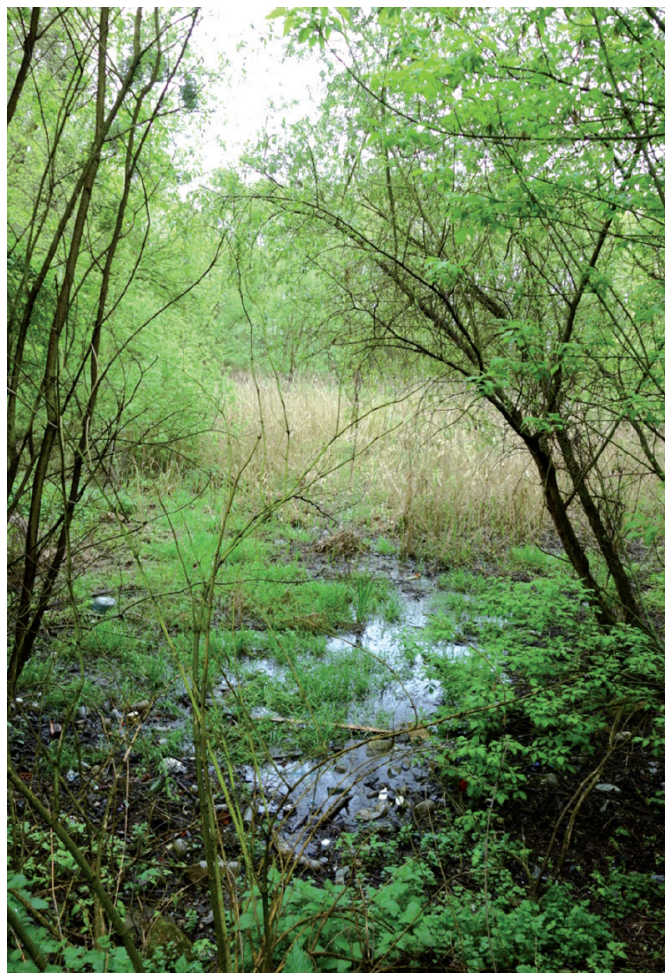

Photo by Sabina Gajczak

Fig. 4. Remains of a pond in the palace park 


\section{Subject matter and method of the study}

Four geoportals were included in the present study. Two of them are nation-wide geoportals, one is maintained at the regional level, and another, at the local level. Geoportals adopted for analysis contain spatial information related to the area in which the valued property is located. The following is a brief description of each of them.

Map portal of the Polish National Heritage Institute (Narodowy Instytut Dziedzictwa) https://mapy.zabytek.gov.pl

The Polish National Heritage Institute (Narodowy Instytut Dziedzictwa, abbreviated as NID) was established by the Minister of Culture and National Heritage on January 1, 2011. It replaced the former National Centre for Historical Monument Research and Documentation. NID has also developed a map portal, which became one of the most popular and the most state-of-the-art tools that provide geospatial information about Polish monuments. Only objects that have been entered in the register of monuments are featured in the portal. Currently you can find there:

- 75,325 spatial objects depicting historic objects (heritage real estate properties);

- 7,752 spatial objects depicting archaeological monuments;

- 92 spatial objects depicting Historic Monuments;

- 32 spatial objects depicting objects from the UNESCO World Heritage list.

Forest Data Bank (Bank Danych o Lasach)

https://www.bdl.lasy.gov.pl/portal/mapy

The Forest Data Bank (Bank Danych o Lasach, abbreviated as BDL) geoportal collects taxonomic descriptions, derived from official documentation, for forests under all forms of ownership. In addition, it features data from the WISL (Wielkoobszarowa Inwentaryzacja Stanu Lasów, i.e. Large Area Forest Inventory), information from phytosociological and habitat studies, and many other kinds of data about forest areas.

Lower Silesia Geoportal (Geoportal Dolny Śląsk)

https://geoportal.dolnyslask.pl/imap/gpmap

The map portal functioning under the name of "Geoportal Dolny Sląsk" ("Lower Silesian Geoportal”) is a modern system that facilitates publishing, analysing, managing and reporting spatial data as well as searching and viewing that data. The whole system is supported by ArcGIS software and web applications. It has been recognized as the most state-of-the-art portal available in Poland today. Based on surveys that assessed its speed of operation, intuitiveness of use, choice of tools, and analytical capacities, it was recognized as the most functional map portal throughout the whole country [Traczyk 2017]. 
Środa Śląska Spatial Information System

(System Informacji Przestrzennej Środa Śląska)

http://gis1.madkom.pl/psip/

Geoinformation portal of the Środa Śląska municipality offers spatial and descriptive data regarding the Środa Śląska municipality. It can be accessed from the homepage of the official website of the municipality. The portal offers the options to view, search, analyse and print descriptive and graphic data. An appraiser and every other user will find there, among other things, the cadastral map, and the map with the Local Spatial Development Plan.

In order to assess the geoportals in terms of their usefulness in the property valuation process, empirical studies of the geoportals were carried out. The original method for assessing the web portals was developed using three categories of attributes [Kozubek and Werner 2009]: functionality, transparency of map portals, and the availability of information about the valued property; the latter being the most important from the property appraiser's point of view.

The functionality category was analysed using criteria such as website user manual, list of available tools, and website navigation. The transparency analysis included the following criteria: link to the geoportal on the office's website, time of the last information update, posting of information on data sharing, and general first impression upon entering the website. The information availability category was assessed using the following criteria: adapting the map content to the user's needs, plot search by number, area measurement, access to the land and mortgage register, access to non-proprietary information from land records, access to historical data, obtaining information on the utilities network, displaying data on the map, data search engine, the ability to change map layers, map key, and the verification of data sources. The analysis uses binary evaluation ( 0 - the feature is not present/is non-existent, and 1 - the feature is present/ it exists). The result of the analysis of the usefulness of the examined geoportals in the process of appraising a given real estate property consists of the totals of points obtained in individual categories, which constitute the overall assessment of the site, and the usefulness of the spatial information contained therein for the property appraiser.

\section{Results analysis}

Table 1 presents a summary of general assessments of individual geoportals in the context of their usefulness in the valuation of the historic real estate property.

Table 1 shows that the overall assessment of geoportals according to the adopted criteria is at the equal level for the nation-wide geoportals, and it increases with the increase in the detail of the spatial information transmitted via the geoportal. In the case of the nation-wide geoportals, the ratio of existing to non-existent features is 12 to 7 , which means that $63 \%$ of the criteria have been met. Although most of the general criteria have been met, the NID geoportal has some disadvantages from the point of view of a property appraiser. For instance, the geoportal contains no instructions that 
would make it possible to quickly learn its functions. Also, no information was included about the time of the latest update. The Forest Data Bank Geoportal has proved to be of little use as a source of information about the real estate property in question. This portal was adopted for the analysis due to the specific nature of the studied property. Within its borders, a wooded area of approximately 15 ha is contained. Unfortunately, the only information found about the property in the BDL portal was an entry stating that it is an unidentified object that belongs to the Miękinia Forest District.

Table 1. Summary of general assessments of individual geoportals

\begin{tabular}{|c|c|c|c|c|}
\hline \multirow[b]{2}{*}{ Categories and features } & \multicolumn{4}{|c|}{ Geoportals } \\
\hline & NID & BDL & $\begin{array}{c}\text { Geoportal } \\
\text { Dolny Śląsk }\end{array}$ & $\begin{array}{c}\text { SIP } \\
\text { Środa Śląska }\end{array}$ \\
\hline \multicolumn{5}{|l|}{ Functionality } \\
\hline Website user manual & & & 1 & 1 \\
\hline List of available tools & 1 & 1 & 1 & 1 \\
\hline Website navigation & 1 & 1 & 1 & 1 \\
\hline \multicolumn{5}{|l|}{ Clarity } \\
\hline Link to the geoportal & 1 & 1 & 1 & 1 \\
\hline Time of the latest update & & 1 & & 1 \\
\hline Information on data sharing & 1 & & 1 & 1 \\
\hline Clarity & 1 & 1 & 1 & 1 \\
\hline \multicolumn{5}{|l|}{ Information availability } \\
\hline Adapting the map content to the user's needs & 1 & 1 & 1 & 1 \\
\hline Plot search by number & & & 1 & 1 \\
\hline Area measurement & 1 & 1 & 1 & 1 \\
\hline Access to non-proprietary information from land records & & & & 1 \\
\hline Access to historical data & 1 & & 1 & \\
\hline \multicolumn{5}{|l|}{ Obtaining information on the utilities network } \\
\hline Displaying data on the map & 1 & 1 & 1 & 1 \\
\hline Data search engine & 1 & 1 & 1 & 1 \\
\hline Ability to change map layers & & 1 & 1 & 1 \\
\hline Map key & 1 & 1 & 1 & 1 \\
\hline Verification of data sources & 1 & 1 & 1 & 1 \\
\hline Total & 12 & 12 & 15 & 16 \\
\hline
\end{tabular}


The analysis of the Lower Silesia geoportal showed that the latter meets 15 out of the 19 adopted criteria, representing $79 \%$ of the maximum total of points. In the category of functionality, the portal obtained the maximum possible number of points. Following the valuation in the category of information availability, we observe that there was no access to the land and mortgage register or to non-proprietary information from land records or to information about the utilities network, which from the point of view of the property appraiser significantly reduces the rating of the portal. On the other hand, a large number of thematic maps about nature, economy, society, tourism, and infrastructure deserve recognition.

The map portal of Środa Śląska municipality received the highest number of 16 points in the overall rating, which is $84 \%$ of all points that are possible for a portal to obtain. The examined map portal lacks only three of the tested features from the category of information availability. These are: access to the land and mortgage register, access to historical data, and information about the utilities network. The local map portal has also proved to be the most useful one from the point of view of a property appraiser. It was the only one that provided access to data from the land register.

\section{Conclusions}

The study analyses geoportals as a source of information about the real estate property being subjected to valuation. Four geoportals were examined: two nation-wide geoportals, one regional, and one local. The geoportals adopted for analysis contain spatial information regarding the area in which the property is located. The analysis indicated that they constitute a valuable additional source of information about real estate.

The analysis showed that the property appraiser would obtain the most information about the property using the geoportal of the National Heritage Institute, and the Środa Śląska Spatial Information System. The first of these geoportals provides a large amount of information on the history of the given real estate property, which is important because of its unique nature. The second contains the current cadastral map and the map featuring the local spatial development plan. In addition, it is possible to gain access to non-proprietary real estate property data from the land and buildings register. The Forest Data Bank contained the least amount of information on the given real estate property. It featured only the information about the forest inspectorate in which the property is located. The Lower Silesia Geoportal, despite having a large number of thematic maps, had proved to be of little use in obtaining information about the real estate property in question. Tourist maps of the region available in the geoportal are nevertheless noteworthy, including the $3 \mathrm{D}$ map - this is due to the nature of the real estate property and its potential use for tourism purposes.

\section{References}

Act 2003. Ustawa z dnia 23 lipca 2003 r. o ochronie zabytków i opiece nad zabytkami (Dz. U. z 2003 r. Nr 162, poz. 1568 z późn. zm.). 
Act 2010. Ustawa $\mathrm{z}$ dnia 4 marca 2010 r. o infrastrukturze informacji przestrzennej (Dz. U. z 2010 r. Nr 76, poz. 489 z późn. zm.).

Bitner A., Bysina J. 2014. A study of real estate market in Kraków using the methods of spatial econometrics. GLL 2, 7-14.

Bogdani M., Grzesik K., Kiziniewicz A., Tarnawski L. 2015. Propozycje weryfikacji metodyki wyceny nieruchomości zabytkowych. Rzeczoznawca Małopolski. Materiały Konferencyjne, 109-120.

Dawidowicz A., Sońta M. 2014. Analiza porównawcza wybranych geoportali europejskich. Acta Sci. Pol., ser. Administratio Locorum, 13(2), 59-76.

Directive 2007. Dyrektywa 2007/2/WE Parlamentu Europejskiego i Rady z dnia 14.03.2007 ustanawiająca infrastrukturę informacji przestrzennej we Wspólnocie Europejskiej (INSPIRE), (Dz. Urz. UE L 108 z 25.04.2007, 1).

Felcenloben D. 2011. Geoinformacja. Wprowadzenie do systemów organizacji danych i wiedzy. Katowice, Wydawnictwo Gall, 241-273.

Gołembski G. (red.). 2005. Kompendium wiedzy o turystyce. Wydawnictwo Naukowe PWN, Warszawa.

Kienast F., Degenhardt B., Weilenmann B., Wäger Y., Buchecker M. 2012. GIS-assisted mapping of landscape suitability for nearby recreation. Landscape and Urban Planning, 105, 385-399.

Kozubek E., Werner P. 2009. Ocena portali internetowych gmin i powiatów. Roczniki Geomatyki, VII, 6(36).

Król K., Szomorowa L. 2015. The possibilities of using chosen jQuery JavaScript components in creating interactive maps. GLL, 2, 45-54.

Nassauer J.I. 2012. Landscape as medium and method for synthesis in urban ecological design. Landscape and Urban Planning, 106, 221-229.

Salata T., Król K., Trystuła A., Koziński G., Skrzatek M., Dawid L., Deska K., Oberski T., Senetra A., Janiszek M. 2015. Rola geoportali w rozwoju i polityce regionów. Wydawnictwo Uniwersytetu Rolniczego w Krakowie, Kraków.

Siejka M., Ślusarski M. 2014. Ocena geoportali internetowych powiatów na wybranych przykładach oraz według ustalonych kryteriów. Infrastruktura i Ekologia Terenów Wiejskich, II (2), PAN, Kraków, 545-555.

Traczyk D. 2017. Ocena geoportali regionalnych z punktu widzenia użytkownika. Wrota Podlasia, 5, 11-44.

Dr hab. Agnieszka Bitner

Uniwersytet Rolniczy w Krakowie

Katedra Geodezji Rolnej, Katastru i Fotogrametrii

30-198 Kraków, ul. Balicka 253a

e-mail: rmbitner@cyf-kr.edu.pl

ORCID: 0000-0002-5733-3987

Dr inż. Karol Król

Uniwersytet Rolniczy w Krakowie

Katedra Gospodarki Przestrzennej i Architektury Krajobrazu

30-059 Kraków, al. Mickiewicza 24-28

e-mail:k.krol@ur.krakow.pl

website: http://homeproject.pl

ORCID: https://orcid.org/0000-0003-0534-8471 
Mgr inż. Piotr Piotrowski

Uniwersytet Rolniczy w Krakowie

Katedra Geodezji Rolnej, Katastru i Fotogrametrii

30-198 Kraków, ul. Balicka 253a

e-mail: piotrowski.pp9@gmail.com

Mgr inż. Sabina Gajczak

absolwentka Wydziału Inżynierii Środowiska i Geodezji

Uniwersytetu Rolniczego w Krakowie

e-mail: s.gajczak@gmail.com 